\title{
Баланс и конфликт интересов стейкхолдеров в стратегических и бизнес-планах компании
}

\author{
Санин В.B. ${ }^{47}$
}

В статье предлагается анализ финансовых отношений, возникаюших в процессе разработки и реализации стратегического или отдельного бизнес-плана компании. Рассматривается пример крупного холдинга. Первичная иель анализа - дать количественную оценку реализуемости планов. Критерием оченки предлагается вероятность возникновения конфликта финансовых интересов среди основных заинтересованных сторон (стейкхолдеров) компании. Для получения данного критерия формулируется методика построения кооперативной теоретико-игровой модели дележа доходов и финансовых результатов компании. Решение модели является балансом интересов, а отклонение от баланса - конфликтом. Информационной базой анализа выступают: финансовая модель компании, организационно-финансовая структура $u$ система мотивации и вознаграждения, разрабатываемая для реализации планов.

Основываясь на приводимом примере, в работе делается индуктивный вывод о возможности $и$ необходимости использования теоретико-игрового подхода $u$ соответствующих критериев оптимальности в практике корпоративных финансов при планировании, заключении соответствующих договоров и соглашений.

С точки зрения практики данная работа может быть актуальна для подразделений компаний, ответственных за стратегическое планирование, а также инвестиционных аналитиков, консультантов, рейтинговых агентств. В теории - для дискуссии между сторонниками теорий максимизации богатства для акционеров (wealth maximization theory) и заинтересованных сторон (stakeholders theory).

\section{JEL: G11, G17, G24, G31, G32, G34, C71, O22}

Ключевые слова: стратегическое планирование, корпоративные финансы, теория стейкхолдеров (заинтересованных сторон), балансировка интересов стейкхолдеров, риск конфликта интересов, кооперативная теория игр

\section{1. Введение. Актуальность темы и целесообразность ее разработки}

Думается, большинство работающих финансовых менеджеров или аналитиков согласится с тем фактом, что собственники и руководители компаний часто принимают серьезные финансовые решения как операционного, так и стратегического характера, руководствуясь не традиционными критериями оптимальности по доходности и рискам, а стремлением удовлетворить в той или иной степени ожидания и интересы различных заинтересованных групп лиц как в самой компании, так и за ее пределами.

В 2004 г. в журнале «Финансы и кредит» была опубликована статья автора «Постановка финансовой цели коммерческого банка: формирование новых подходов» [Санин, 2004]. В статье отстаивалась идея о том, что финансовая цель крупной корпоративной структуры, в частности коммерческого банка, должна формулироваться на основе баланса интересов всех заинтересованных сторон (стейкхолдеров) ее бизнеса. Эта идея базировалась на популярной в западных деловых кругах теории заинтересованных

\footnotetext{
${ }^{47}$ Соискатель ученой степени канд. эконом. наук Санкт-Петербургского государственного университета экономики и финансов; последнее место работы - ведущий аналитик дирекции по связям с инвесторами ООО «ЛСР. Управляющая компания» (холдинг «Группа ЛСР»)
}

Выпуск \#2(10), 2009

(C) Электронный журнал Корпоративные Финансы, 2009 
сторон, основоположником которой считается Э. Фримен [Freeman, 1984]. Однако эта теория не определяла, как найти компромисс между заинтересованными сторонами, в какой пропорции удовлетворять конкурирующие интересы, то есть не предлагала методику и необходимый математический аппарат. В статье было предложено понятие финансового конфликта (баланса) как структурной диспропорции (пропорции) в распределении доходов и расходов, рисков и обязательств между стейкхолдерами компании и выдвигалась гипотеза о возможности определения конфликта (баланса) интересов посредством математического аппарата теории игр.

При разработке корпоративной стратегии поиск баланса интересов стейкхолдеров вступает в противоречие с целевым критерием максимизации стоимости бизнеса для акционеров (wealth maximization theory), в частности рыночной стоимости акций («market capitalization»). В популярности последнего показателя в России не последнюю роль сыграл бум публичных (IPO, SPO) и частных размещений акций, а также рост рынка сделок слияния-поглощений (M\&A), прошедших в период 2000-2008 гг. Следует полагать, что, даже несмотря на текущий мировой финансовый кризис, акционерные формы финансирования развития бизнеса в России будут набирать в ближайшие десятилетия обороты, и данный показатель не утратит своих позиций. Кризис только усилит внимание фондового рынка к качеству инвестиционного анализа и оценки инвестиционного риска при вложении средств в того или иного эмитента. Таким образом, необходим компромисс между максимизацией стоимости бизнеса для акционеров и поиском баланса интересов стейкхолдеров.

Еще одним фактором актуальности является вопрос, интересующий фондовых аналитиков и инвесторов при оценке риска вложения в акции развивающихся компаний, насколько реалистичны, адекватны и реализуемы планы эмитента? Аналитики отвечают на этот вопрос при анализе финансовой модели и данных эмитента путем сопоставления рыночных прогнозов (входящих и исходящих цен и объемов сырья и продукции), сделанных эмитентом и собранных самостоятельно. Вместе с тем, как показывает практика, порядка 90\% долгосрочных прогнозов фондовых аналитиков оказываются ошибочными. Другими словами, проводимой проверки и объема используемых данных явно недостаточно. Вместе с тем многие консалтинговые фирмы заявляют, что эмитент может реализовать планы в полной мере и в указанные сроки только при условии наличия в его планах баланса интересов стейкхолдеров. Однако, опять же, консультанты не говорят, как его искать, ограничиваясь вербальными рекомендациями.

Отдельные участки столкновения интересов стейкхолдеров современная финансовая теория не оставляет без внимания. В первую очередь речь идет о корпоративном треугольнике «акционеры - совет директоров - менеджмент». На практике получили распространение различные опционные программы для членов совета директоров и топменеджеров компаний с привязкой показателей к стратегии и создаваемой стоимости. Для снижения рисков инвесторов на фондовом рынке рейтинговые агентства стали уделять пристальное внимание внутрикорпоративным отношениям эмитентов, особенно растущих, привлекающих акционерный капитал. Например, агентство Standard\&Poor's (S\&P) в последние годы активно продвигает свой рейтинг корпоративного управления (РКУ). В описании методологии рейтинга декларируется: «РКУ - это мнение S\&P о степени, в которой компания применяет общепризнанные лучшие принципы корпоративного управления, призванные служить интересам финансово заинтересованных лиц, в первую очередь акционеров. В ходе присвоения РКУ исследуется механизм взаимодействия между руководством компании, советом директоров и акционерами, направленный на обеспечение адекватного распределения доходов между всеми заинтересованными лицами» [Standard\&Poor's, 2005]. Вместе с тем анализ анкет, предлагаемых агентством компаниям к заполнению для получения РКУ, показывает, что в основном проводится анализ взаимоотношений с упором на его правовые основы и нормы, закрепленные в 
общекорпоративной документации, а не исследуются детали финансовых планов и соглашений. Но в любом случае рейтинги корпоративного управления на сегодняшний день - это единственный практически используемый инструмент анализа, сопоставляющий стратегию компании и отношения части ее заинтересованных сторон. Только методологии РКУ не хватает финансово-математического аппарата анализа и более широкого взгляда на перечень стейкхолдеров.

Среди попыток создания инструментов анализа стратегии через призму отношений стейкхолдеров выделим для данной статьи работы несколько авторов.

В первую очередь, это публикации коллектива кафедры экономики и финансов ГУ ВШЭ и ее руководителя И.В. Ивашковской. Э.Р. Байбурина и Т.В. Головко заметили «что включение групп внутренних и внешних стейкхолдеров значительно усложняет анализ процесса управления стоимостью компании... Помимо менеджмента необходимо также рассматривать интересы ключевых групп сотрудников, обладающих специфическими или ключевыми знаниями для компании...» [Байбурина, Головко, 2008]. Исследователи предлагают концепцию управления интеллектуальной стоимостью компании (Intellectual Value Based Management), где стоимость рассматривается как интеллектуальный параметр, определяемый многоуровневой комбинацией взаимодействия всех внутренних и внешних стейкхолдеров. Для отражения вклада стейкхолдеров в создание стоимости предлагается разрабатывать индексы вклада стейкхолдеров (stakeholder value index), направленные на оценку соотношения накопленного потока экономической прибыли компании и издержек на выстраивание отношений со стейкхолдерами [Ивашковская, 2008]. Устойчивые связи стейкхолдеров формируют интеллектуальный капитал компании, который привносит ощутимый вклад в стоимость ее бизнеса [Байбурина, Ивашковская, 2007]. Коллектив кафедры пока сконцентрировался на эконометрическом анализе связей стейкхолдеров и влиянии этих связей на стоимость, не подступаясь к моделированию всей системы финансовых отношений стейкхолдеров и не рассматривая фактор конфликта интересов.

Отметим работу М.А. Петрова, заявившего, что «качество стратегии фирмы может рассматриваться с точки зрения ее способности удовлетворять интересы (требования) заинтересованных сторон» [Петров, 2005]. Петров сформулировал балансовую модель ресурсных отношений, дающую возможность оценить сбалансированность ресурсного обмена между заинтересованными сторонами. Общим знаменателем интересов предлагаются ренты, «которые фирма генерирует в результате своей деятельности и которые распределяются между ее стейкхолдерами», т.е. по сути речь идет о доходах и финансовых результатах компании. Задачу согласования интересов автор сводит к экстремальной задаче линейного программирования, исходя из предположения, что стороны стремятся максимизировать свои интересы и допустимое множество решений задачи является непустым. Если множество не пустое, то стратегия является реализуемой. Последнее утверждение верно. Однако при стремлении сторон максимизировать интересы при распределении доходов и финансовых результатов корпорации допустимое множество решений оказывается именно пустым. То есть сумма финансовых интересов и требований часто превышает подлежащие к распределению финансовые ресурсы. Иными словами, модель Петрова не учитывает конфликтный характер отношений заинтересованных сторон, а если и пытается учесть, то предлагает менеджменту искать альтернативу в распределении рент между заинтересованными сторонами интуитивно или методом перебора вариантов, так как предлагаемый математический аппарат для подобных задач не предназначен.

Из зарубежных авторов, связывающих отношения заинтересованных сторон и стратегию компании, выделим работу М. Йенсена [Jensen, 2001]. Он сформулировал мысль о том, что целевая функция компании «максимизация стоимости» с учетом теории заинтересованных сторон должна трансформироваться в функцию «поиска стоимости», то есть речь должна идти не о максимизации, а о поиске оптимума при планировании стоимости. Но модельного обоснования автор не предлагает. 
Подведем итог небольшого анализа актуальности и целесообразности исследования критерием анализа стратегии на реализуемость является баланс интересов стейкхолдеров компании, но финансовая теория не предлагает модельно-методического аппарата для анализа и согласования конфликтующих интересов. Также необходимо найти компромисс между критерием максимизации стоимости для акционеров и поиском баланса интересов стейкхолдеров.

Конфликтный характер отношений стейкхолдеров подталкивает к использованию теоретико-игровой математики для их моделирования и оптимизации. При этом столкновение интересов стейкхолдеров в бизнесе компании носит характер не просто конфликта, но конфликта при кооперации. Поэтому наибольший интерес для моделирования представляет кооперативный раздел теории игр.

Прежде чем приступить к моделированию, определим, что мы понимаем под «заинтересованными сторонами» и их «интересами». Остановимся на понятийном аппарате, информационной базе анализа, а также некоторых допущениях и ограничениях, принятых в исследовании.

\section{2. Понятийный аппарат, информационная база и основные допущения моделирования}

Для начала определим, какие компании исследуются.

Для примера возьмем крупную корпорацию (с годовым оборотом, условно, от 500 млн долларов), имеющую диверсифицированную структуру активов, юридически оформленную в холдинг (понятия «холдинг», «корпорация», «фирма», «компания» используются как синонимы). По большей части исследование ориентировано на компании, представленные на фондовых площадках в России и за рубежом, а также достигшие потребности в акционерном финансировании своего развития и готовящиеся привлечь капитал публичным или частным образом.

На практике автором исследованы два типа юридических структур холдингов - двухи трехуровневые. В первом случае холдинговая компания владела бизнес-объектами напрямую, во втором - через субхолдинговые компании. При этом роль управляющей компании (УК) может выполнять как холдинговая (материнская) компания, так и отдельное юридическое лицо, имеющее договор с холдинговой компанией на управление ее активами.

Рассмотрим для примера условный многопрофильный холдинг с трехуровневой структурой. Материнская компания выступает корпоративным центром, владеющим и управляющим субхолдинговыми компаниями, а последние, в свою очередь, владеют и управляют отдельными бизнес-направлениями. Подчеркнем, нас интересуют только холдинги с четко выстроенной структурой владения, которая необходима для такого инструмента привлечения капитала, как IPO, а часто и для сделок M\&A.

Определим роль УК в управлении холдингом. Условно выделяют четыре варианта модели корпоративного центра [Фут, Хенсли, Лэндсберг, Моррисон, 2003]:

- финансовый холдинг,

- стратегический архитектор (СА),

- стратегический контролер (СК),

- оператор.

Это двухполюсная классификация, основанная на степени централизации управления. Часто холдинги эволюционируют в ходе своего развития от операционного к финансовому холдингу, постепенно уменьшая централизацию. Так, для многих российских холдингов сегодня актуальна модель СК, на которой мы остановимся в нашем примере.

Помимо УК в структуре холдинга, как правило, выделяют бизнес-единицы (БЕ) и бизнес-объекты (БО). Соответственно БО - это конкретное предприятие холдинга, производящее и реализующее определенный набор продуктов. Часто на практике в целях оптимизации налогообложения и снижения хозяйственных и имущественных рисков одно 
предприятие может быть представлено двумя или тремя (и более) юридическими лицами, где первое, например, выступает владельцем имущественного комплекса, второе - арендатором первого, а также владельцем кадров, а третье - коммерческим подразделением, сбытовиком и/или поставщиком сырья для производства. При разработке стратегических и бизнес-планов такие юридические лица рассматриваются как одна фирма.

БО объединяются в БЕ по продуктовому, географическому или иному признаку. Здесь стоит упомянуть требования международных стандартов финансовой отчетности (МСФО), так как консолидированная отчетность большинства российских холдингов составляется именно на этой основе. При проектировании юридической и управленческой структур многопрофильным холдингам желательно сразу учитывать стандарт МСФО 14 «Сегментная отчетность», во избежание последующих проблем в диалоге с аудиторами и инвесторами.

Для целей удобства во владении и управлении БЕ нередко объединяют по отраслевой принадлежности, образуя бизнес-направления. В рассматриваемой нами трехуровневой юридической структуре субхолдинговые компании, владеющие и управляющие бизнеснаправлениями, будут называться продуктовыми компаниями (ПК). Таким образом, исходная организационная структура, совмещающая юридическую и управленческую, будет выглядеть следующим образом (рис. 1).

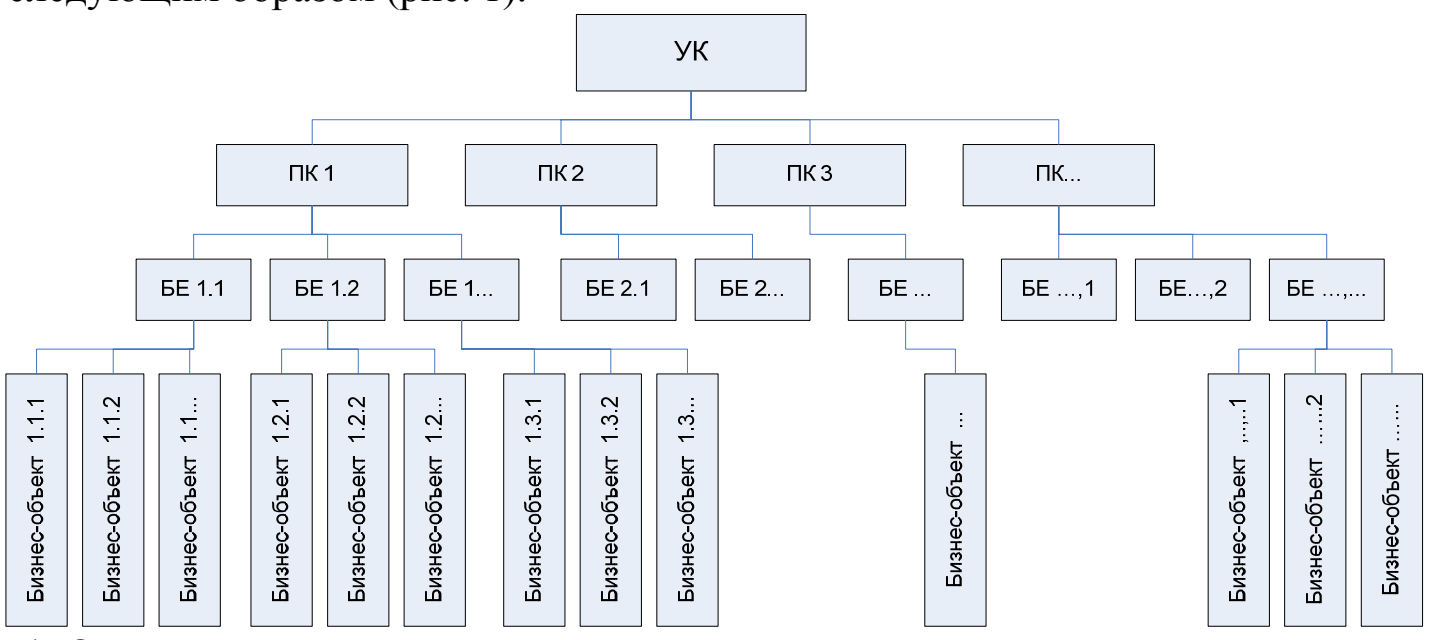

Рис. 1. Организационная структура холдинга

Перейдем к понятию «стратегия» и процессу ее разработки (здесь и далее «стратегия», «корпоративная стратегия», «инвестиционная стратегия», «стратегия развития» - синонимы).

Современная теория располагает большим разнообразием подходов к разработке стратегии. Мы возьмем за основу классический подход, принятый на вооружение большинством западных компаний [Идрисов, Картышев, Постников, 2003]. Основными представителями этого подхода в мировой практике являются такие консультационные фирмы-гиганты, как McKinsey, AT Kearney, BCG, Bain, Monitor, Mercer и др. Финансовой целью стратегии в этом подходе, как отмечалось, выступает максимизация акционерной стоимости (рыночной капитализации, Мсар) компании. Принимая за основу для моделирования действующую практику, будем исходить из того факта, что корпоративная стратегия в своем первоначальном варианте разрабатывается именно по критерию максимизации стоимости для акционеров, а затем на этапе ее анализа рассматриваются стейкхолдеры с их требованиями и ожиданиями.

Стоимость компании в наибольшей степени зависит от двух основных показателей: полученной прибыли за период и будущих дисконтированных денежных потоков от сделанных и планируемых инвестиций, то есть потенциала создания стоимости, другими словами, стратегии. 
С маркетинговой точки зрения целью стратегии являются конкурентные преимущества. Причем последние могут быть не только у создаваемых компанией продуктов (цена и качество), но и у структуры компании - в виде уникальной цепочки создания стоимости [Скотт, 2005]. Это значит, что компания должна уметь не только создать «хороший» продукт, но и произвести его с приемлемыми затратами, а также суметь продать по цене, гарантирующей прибыль.

Для того чтобы увязать финансовую и маркетинговую трактовки, возьмем за аксиому, что конкурентные преимущества (КП) создаются за счет инвестиций (И), тогда формула стратегии:

$\Delta M c a p=f(K \Pi(И))$

или упрощенно:

$$
\Delta \text { Mcap }=f(И) .
$$

Тогда под стратегией холдинга в нашем примере будет пониматься инвестиционная стратегия, направленная на максимизацию прироста стоимости его акций. Дельта в формуле (1) указывает на то, что стратегия создает потенциал создания стоимости. Существующие

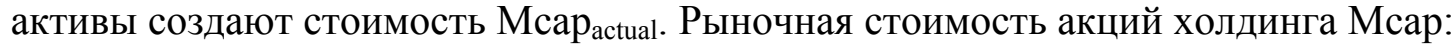

$$
\text { Mcap }=\text { Mcap }_{\text {actual }}+\Delta \text { Mcap } \text {. }
$$

Инвестиционная стратегия - это совокупность инвестиционных проектов. Под инвестиционным проектом (ИП) будет пониматься целевое вложение капитала в основные средства БО сроком более чем на один год и на сумму более 1 млн долларов США. Следует подчеркнуть, что мы разделяем вложения в основные средства и наращивание оборотного капитала, которые различаются так же, как понятия «развитие» и «рост». Рост - это категория в большей степени операционной, «развитие» - стратегической деятельности.

Разработка стратегии распределяется по организационной структуре холдинга. УК формирует корпоративный портфель (совокупность БЕ холдинга), отбирая БЕ по таким критериям, как рост рынка, доля рынка, рентабельность, вклад в денежный поток, инвестиционный риск (ставка дисконтирования), синергия с другими БЕ и др. Затем ПК формирует портфель инвестиционных проектов на уровне своих БЕ.

Стратегия разрабатывается в форме презентации и финансовой модели.

Основными отчетными формами финансовой модели традиционно являются отчеты о прибылях и убытках, агрегированном балансе и денежных потоках (бывает, что баланс не строят). Как правило, предусматриваются три сценария динамики продаж холдинга оптимистичный, базовый и пессимистичный. В каждом варианте предусмотрена своя инвестиционная программа, отличная как по объему, так и по структуре инвестиционных проектов, то есть по сути разрабатываются три самостоятельные модели. Мы рассмотрим только базовый вариант. Стратегия и соответственно модель разрабатывается на срок пять лет со скользящим механизмом планирования - ежегодной корректировкой и разработкой плана на последующие пять лет. При этом модели отдельных инвестиционных проектов могут разрабатываться и на большие сроки, но в рамках консолидации в общую модель сводятся к указанному сроку (с перераспределением стоимости бизнеса между дисконтированным денежным потоком и остаточной стоимостью). Структура модели, согласуясь со структурой финансовой отчетности в холдинге, будет трехуровневая: «БО $\rightarrow$ БЕ $\rightarrow$ Холдинг», с учетом необходимых принципов консолидации. Детализация консолидированной модели ограничивается агрегированными продуктовыми группами, без конкретизации цен и затрат по каждому продукту БО. Стоимость холдинга, опять же в целях упрощения, будет равна сумме стоимостей БЕ. Предполагается, что синергия БЕ учтена при планировании совместного (перекрестного) использования различных ресурсов, в частности основных средств и заемного капитала.

В процесс стратегического планирования часто включают не только разработку стратегии, но и этап ее внедрения в структуры холдинга. Внедрение подразумевает как минимум выстраивание необходимых структур управления, прописывание процедур и 
регламентов, а также разработку системы мотивации и вознаграждения, направленную на реализацию стратегии.

Остановимся на организационно-финансовой структуре.

Эта структура в нашем случае должна распределять ответственность за реализацию инвестиционных проектов по организационной структуре холдинга. Поэтому правильнее ее было бы называть организационно-инвестиционной или организационно-стратегической структурой. Здесь возникает вопрос о связи и принадлежности этой структуры структуре центров финансовой ответственности (ЦФО), разрабатываемой в рамках методологии бюджетирования на предприятии (см., например, [Добровольский, Карабанов, Боровиков, Глухов, Бреслав, 2006]). Первоначально хочется ответить утвердительно, но это не так.

Дело в том, что продвигаемые сегодня в России консультантами системы бюджетирования и управленческого учета (методология плюс программный продукт) - это операционные системы. Причем речь идет не только о классическом варианте методологии бюджетирования, где затраты компании группируются по ЦФО, но и о новом варианте - с группировкой по бизнес-процессам (см., например, [Бримсон, Антос, 2007]). Подобные системы позволяют достаточно эффективно управлять операционной деятельностью с горизонтом планирования до одного года, но слабо предназначены для регулярной инвестиционной деятельности. Достаточно сказать, что под центром инвестиций в рамках терминологии ЦФО понимается самый верхний уровень финансовой структуры холдинга, а все нижестоящие центры - либо центры прибыли, либо затрат. Если следовать этой логике, реализацию 10-50 ИП, на которые раскладывается стратегия, должен проводить совет директоров (СД) или УК.

Для реализации стратегии ведущие западные компании выстраивают инвестиционные структуры управления, параллельные операционным, так как структура управления, характеризующая уже сложившийся бизнес и описываемая структурой ЦФО, не предназначена для реализации стратегии. Инвестиционные структуры и есть «структуры развития». В России последние несколько лет структуры управления ИП стали активно формироваться в нефтегазовых и некоторых других экспортно ориентированных отраслях, однако в целом эти попытки в масштабах всей экономики пока явно незначительны.

В нашем примере будем исходить из того, что рассматриваемый холдинг обладает или разрабатывает подобную структуру - имеются необходимые регламенты и положения, описывающие систему инвестиционного бюджетирования и учета (в литературе можно встретить термин «проектный учет»). Инвестиционный учет - это, как минимум, выделенная совокупность счетов исходя из кодификации всех инвестиций и соответствующие правила работы по этим счетам. Операционный и инвестиционный учеты вместе формируют полную систему управленческого учета компании.

Введем понятия центров оперативной и инвестиционной ответственности. Если предприятие получает инвестиции, то в нем формируется «центр инвестиционной ответственности» (ЦИО), если не получает, то остается «центром оперативной ответственности». Иными словами, холдинг управляет предприятиями без инвестиций через структуру ЦФО, а инвестициями - структурой ЦИО. В нашем примере предполагается, что все БО получили инвестиции.

Методология управления проектами предлагает различные подходы и методики распределения инвестиционной ответственности. У нас субъектами инвестиционной ответственности в холдинге выступят СД, УК, ПК, БО, а сама ответственность будет распределяться по матрице ответственности, формируемой такими критериями, как количество ИП и размер инвестиций, участие в определенном этапе инвестиционного процесса и функционал-роль в инвестиционном процессе.

Структура ЦИО и матрица инвестиционной ответственности выступают основой для распределения ответственности за реализацию финансовой модели как по вертикальным, так и по горизонтальным связям холдинга. Распределение ответственности является базисом для 
стратегических мотивационных схем и программ, в частности корпоративной системы бонусов для наших субъектов инвестиционной ответственности.

Бонусы УК, ПК и БО от реализации стратегии могут быть «привязаны» к соответствующим показателям выручки, EBITDA и инвестициям, например, по следующей схеме:

$$
\text { Бонус }=\tau\left(a_{1} \text { Sales }+a_{2} \text { EBITDA }+a_{3} \text { Inv }\right),
$$

где $\tau$ - размер бонуса, как правило, в виде незначительного процента (доли),

$\mathrm{a}_{1}, \mathrm{a}_{2}, \mathrm{a}_{3}$ - оценка вклада субъекта инвестиционной ответственности в достижение показателей стратегии, причем $\mathrm{a}_{1}+\mathrm{a}_{2}+\mathrm{a}_{3}=1$. Соответственно УК привязаны к показателям консолидированной модели, ПК - своих БЕ, БО - своих ИП.

Корпоративная система бонусов является элементом ключевых понятий нашей работы - стейкхолдеры и их интересы.

Самое первое определение Э. Фримена гласит, что стейкхолдеры (stakeholders) - это «любые индивидуумы, группы или организации, оказывающие существенное влияние на принимаемые фирмой решения и/или оказывающиеся под влиянием этих решений» [Freeman,1984, p. 25] (термины «стейкхолдеры», «заинтересованные стороны», «группы влияния», «игроки» - синонимы). Современные отчеты компаний по корпоративной социальной ответственности дают такое определение - это физические и юридические лица, заинтересованные в финансовых и иных результатах деятельности компании и способные оказывать влияние на нее. Это определение экономически, а точнее финансово, более узкое, поэтому остановимся на нем.

Как правило, в академических работах разные авторы приводят примерно одинаковый перечень заинтересованных сторон фирмы. Для холдинга можно встретить следующий (рис. 2).

На практике некоторые компании ограничивают круг своих заинтересованных сторон только акционерами, менеджментом, сотрудниками, клиентами и органами власти (см., например, [Стратегия КСО МБРР, 2008]). Некоторые расширяют его, включая общество (в целом), сообщества в регионах, неправительственные организации, средства массовой информации, рейтинговые агентства и даже конкурентов (см., например, [Стратегия КСО МДМ Банка, 2007]. Все зависит от масштабов бизнеса компании и ее рыночного самопозиционирования.

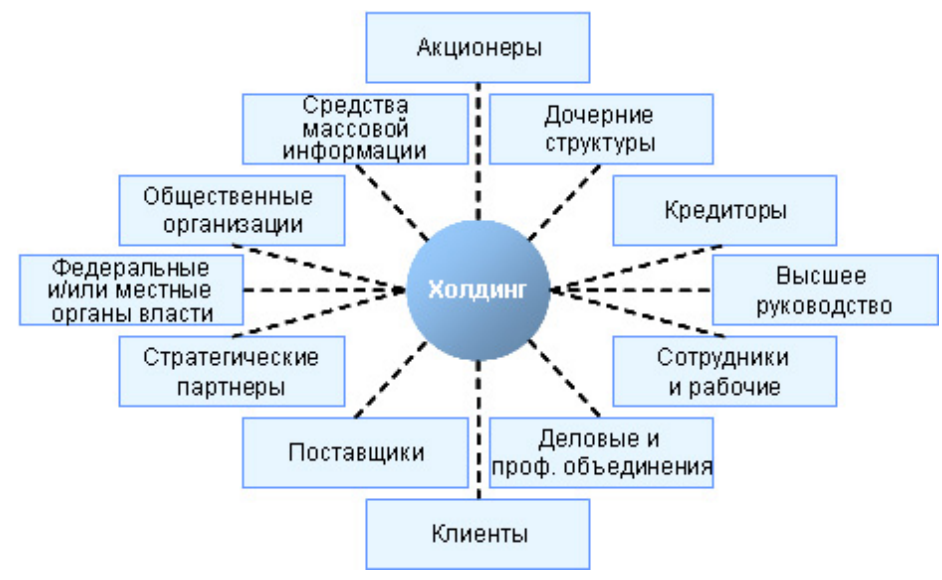

Рис. 2. Стейкхолдеры холдинга

Предположим, наш холдинг при разработке стратегии желает определить «внутрихолдинговый» баланс интересов: между акционерами, дочерними структурами, высшим руководством, сотрудниками и рабочими. Также предполагается учесть интересы ключевых клиентов и основных поставщиков - «микроэкономического» круга, а затем планируется включить интересы общественных организаций и местных органов власти «макроэкономического» круга (рис. 3). Такой перечень сформирован критерием силы 
влияния заинтересованной стороны и близости ее интересов к инвестиционным расходам и доходам холдинга.

Все заинтересованные стороны холдинга имеют свои финансовые интересы. Под финансовым интересом стейкхолдера будет пониматься ожидаемая им экономическая выгода от реализации стратегии, выраженная в финансовой форме (денежной, временной и, по возможности, рисковой).

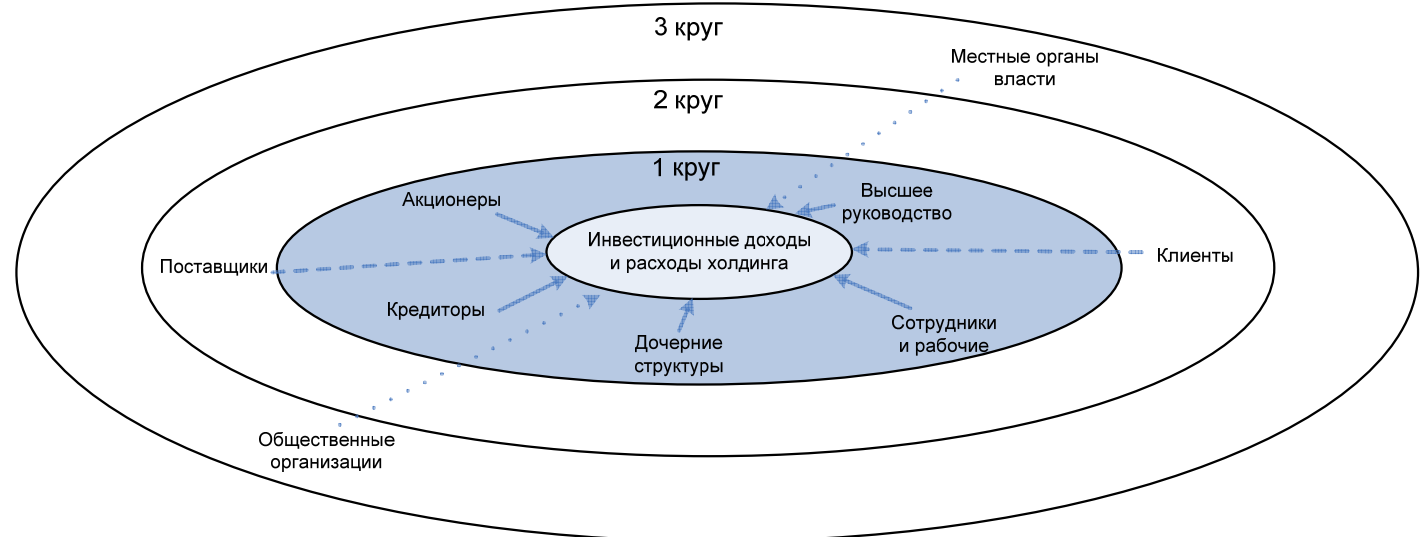

Рис. 3. Структуризация стейкхолдеров для рассматриваемого примера

Финансовые интересы акционеров в стратегии могут быть выражены показателем прироста рыночной капитализации, доходностью вложенного капитала, уровнем инвестиционного риска, дивидендными выплатами. Для России, в отличие от западной практики, остро стоит проблема формулировки интересов собственников, так как последние часто не разделяют термины «владеть» и «управлять». Собственник не должен формулировать свои интересы в терминах управления, а только в терминах «владения», при этом он может и должен осуществлять контроль управления и оценивать влияние управленческих решений на доходность «владения».

Высшее руководство, совет директоров и топ-менеджеры рассчитывают на бонусы в размере определенной доли или процента от прироста стоимости акций посредством, например, тех же опционов.

Дочерние структуры, как отмечалось, могут получать различные премии и бонусы, привязанные к показателям выручки, прибыли, инвестиций от реализуемых проектов.

Для мотивации сотрудников и рабочих холдинга, находящихся внутри управляющей и дочерних структур также могут использоваться различные бонусные схемы в привязке к отдельным ключевым показателям эффективности (KPI) инвестиционных проектов.

Подчеркнем, мы различаем бонусную и премиальную системы. Бонусная отличается тем, что дает возможность структурным подразделениям холдинга планировать свой заработок, активно добиваясь его реализации. Поэтому бонусная система актуальна именно для инвестиционно-стратегической работы, тогда как премиальная - в большей степени для операционной.

Для моделирования необходимо классифицировать финансовые интересы высшего руководства, дочерних структур, специалистов и рабочих холдинга. В качестве базиса для такого классификатора мы предлагаем вариант финансовой модели и организационнофинансовой структуры (структуры ЦИО), построенных с учетом юридической и управленческой структур холдинга.

Рассмотрим пример системного подхода к построению корпоративной системы бонусов для реализации стратегии. Сначала идет стратегическое распределение выгод между акционерами, СД, УК, ПК и БО (уровень 1), затем формируемые бонусные фонды распределяются внутри юридических лиц холдинга между его руководством и структурными подразделениями (уровень 2) и, наконец, на заключительном этапе идет распределение персональных бонусов внутри отделов и служб, участвующих в реализации проектов 
(уровень 3). На практике и в теории можно встретить различные подходы к построению проектных схем мотивации (например, [Куршева, 2006], [Дымшаков, 2004], [Брауде, Ефименко, Леонова, 2004]), но главное, подчеркнем, - нужно различать и разделять операционные и инвестиционные схемы. Например, генеральный директор БО, получающего инвестиции, (помимо премий за операционные результаты) планирует и отстаивает бонус своего предприятия от реализации определенного проекта.

При включении в перечень стейкхолдеров клиентов и поставщиков, общественных организаций и местных органов власти их интересы оцениваются и включаются в первый уровень.

Финансовыми интересами поставщиков и клиентов предприятий холдинга выступают цены, объемы и нередко сроки поставок по входящим и исходящим товарным потокам.

Общественные организации часто представляют интересы местных сообществ населения тех регионов, городов или их районов, в которых холдинг ведет бизнес, - это может быть защита окружающей среды, увеличение возможностей по трудоустройству, спонсорство, финансирование отдельных мероприятий и прочее.

Местные органы власти также часто выдвигают свои финансовые требования к крупным холдингам - это может быть рост налоговых поступлений, благоустройство территорий, опять же, финансирование отдельных, например, городских программ и мероприятий. В любом случае, как интересы общественных организаций, так и органов власти для холдинга с финансовой точки зрения - дополнительные, часто не предусмотренные первоначально, расходы. Выявить и оценить их, на этапе анализа стратегии, перед началом ее реализации, - важнейшая и необходимая работа аналитиков и руководителей холдинга.

Интересы кредиторов, в частности, инвестиционных и коммерческих банков, - это, в первую очередь, процентные ставки по кредитам и займам, а также цена дополнительных услуг. Если по кредитованию операционной деятельности процентные ставки, как правило, более-менее понятны с точки зрения финансового моделирования, то интересы инвестиционного банка при выходе холдинга на IPO или финансировании крупной инвестиционной программы явно подлежат обсуждению и согласованию.

Интересы стейкхолдеров в каждом конкретном холдинге и для каждой конкретной рыночной ситуации могут выявляться и формулироваться по-разному, с разной степенью адекватности рынку, отраслевым стандартам, с разной степенью обоснованности. Как показывает практика, чаще всего интересы формулируются либо сразу по максимальной планке выгоды, либо указывается ее «вилка», минимаксный коридор. Собственно, именно стремление к максимизации своей выгоды заинтересованной стороной создает условия для финансовой конфликтологии, как направления исследований о противоречии и столкновении финансовых интересов, и вынуждает искать баланс интересов.

Далеко не все интересы максимизуются. Мы будем разделять интересы постоянные и переменные. Например, заработная плата менеджеров, специалистов и рабочих, а также процентная ставка по операционным кредитам и займам часто прописываются в финансовых моделях как условная константа, и, конечно, такая выгода стейкхолдеров подлежит безусловному возмещению. Мы не будем рассматривать в наших примерах обратные ситуации (например, невыплата зарплаты рабочим) как примеры финансовых конфликтов (хотя они таковыми являются). Переменная же часть - бонусы от реализации стратегии и отдельных проектов, ситуации их распределения, наоборот, будут являться нашими примерами.

Надо понимать, что даже первый «внутрихолдинговый» круг интересов неоднороден с точки зрения критерия силы влияния сторон. Основной властью при распределении финансовых ресурсов чаще всего обладают акционеры (в основном мажоритарии), а также высшее руководство. Соответственно, заложенные в финансовую модель пропорции интересов часто идут не в пользу стоящих ниже по иерархии. Поэтому наиболее 
распространены в российской практике финансовые конфликты по вертикали структур холдинга, далее следуют горизонтальные - между ПК или между БО. Степень конкуренции во многих российских отраслях и на многих рынках разная, поэтому встречаются и конфликты корпораций с их поставщиками и клиентами. Например, можно вспомнить недавние российские новости о межкорпоративных конфликтах по ценам на авиатопливо и ГСМ для сельхозпроизводителей.

Учитывая различную силу влияния стейкхолдеров, в современной практике проверять степень готовности холдинга к реализации стратегии через определение баланса интересов, скорее всего, должно рейтинговое агентство, внешний консультант или аналитик инвестиционного банка. Хотя в идеале эта задача должна стать внутрикорпоративной функцией, например, совета директоров холдинга. Пока же вариант рейтингового агентства видится наиболее предпочтительным, так как оно уже анализирует стратегии и планы эмитентов и, по определению, работает в интересах потенциальных инвесторов. Последние и являются, как правило, основными пользователями результатов проверки.

Теперь приступим к математической формулировке модели (задачи) определения финансового баланса/конфликта интересов стейкхолдеров в стратегии компании.

\section{3. Математическая формулировка задачи и ее решение}

Исходим из того, что на рабочем столе аналитика имеются следующие данные:

- стратегия холдинга (презентация и финансовая модель),

- документы, раскрывающие юридическую, управленческую и организационнофинансовую структуры холдинга, подготовленные к реализации стратегии.

Также необходимы документы, раскрывающие структуру и показатели корпоративной системы бонусов, распределяемой между внутренними стейкхолдерами, которые должны присутствовать и в финансовой модели. Если таковые имеются, то перед аналитиком стоит задача оценки риска конфликта интересов. Она включает в себя анализ обоснованности и рыночной адекватности интересов стейкхолдеров, определение баланса интересов и оценку степени отклонения структуры интересов в финансовой модели от найденного баланса. Если же система бонусов отсутствует, то задача ограничивается выявлением, формулировкой и балансировкой интересов.

Предполагается, что аналитик имеет доступ к рыночной (отраслевой и биржевой) информации и независимым прогнозам, который позволяет оценить адекватность рынку и ситуации в холдинге желаемых бонусов, а также показателей входящих и исходящих цен и объемов по сырью и продукции.

Учитывая развитие современных информационных систем, можно сказать, что проблема доступа к подобной информации не представляется существенной. Информационные системы Bloomberg и Reuters дают доступ ко всей обязательной и раскрываемой информации по десяткам тысяч компаний по всему миру. К примеру, размеры бонусов членов совета директоров и ключевых менеджеров, а также важнейшие условия договоров с ними обязательны к раскрытию для инвесторов по законодательству США. Также при внедрении компаниями программ долгосрочного вознаграждения МСФО требуют указывать расходы, связанные с программой, в частности, в отчете о прибылях и убытках и давать пояснения в расшифровках. Меморандумы эмитентов часто раскрывают информацию об используемых в компании системах мотивации. Другими словами, собрать подобную информацию при желании возможно.

Также традиционной информационной базой для работы рейтингового агентства являются опросы руководителей и специалистов холдинга. Предполагается, что у аналитика есть возможность провести диалог с представителями стейкхолдеров, заинтересованными в реализации стратегии, и услышать доводы и обоснования желаемых выгод.

Определим, какую модель мы должны построить для нахождения баланса интересов. 
Теория игр занимается изучением конфликтов, то есть ситуаций, в которых группе людей необходимо выработать какое-либо решение, касающееся их всех. Некооперативная теория игр изучает то, как должны действовать игроки, чтобы прийти к тому или иному результату; кооперативная же теория игр изучает вопрос о том, какие возможные исходы являются справедливыми с той или иной точки зрения. Нас интересует последняя.

В первую очередь, основываясь на доступной информации, а также руководствуясь принципом понятности, гибкости и простоты практического применения, остановимся на моделях распределения (рационирования, дележа) [Мулен, 1991].

В общем виде задачу дележа $D$ можно описать следующим образом:

(4)

$$
D=(I, r, X) \text {, }
$$

где:

I - игроки,

$\mathrm{r}$ - ресурс, подлежащий распределению,

$\mathrm{X}$ - вектор интересов, где $\mathrm{x}_{\mathrm{i}}-$ интерес игрока $\mathrm{i}, \mathrm{i} \in \mathrm{I}$.

Суть конфликта интересов сводится к тому, что сумма интересов превышает ресурс, подлежащий распределению:

$$
\sum_{i \in I} x_{i}>r .
$$

Интересы формулируются на практике, как отмечалось, двумя способами: $\left(x_{i}^{\max }\right)$ или коридором $\left(x_{i}^{\min } ; x_{i}^{\max }\right)$. Нижняя граница интереса - это значение, ниже которого игроку невыгодно вступать в кооперацию и он однозначно разорвет (саботирует) отношения с холдингом. Верхняя граница - это традиционно максимально возможная по отраслевым меркам выгода игрока, а часто и превышающая его при дополнительной «завышенной» ответственности и риске. Сначала рассмотрим первый способ.

Решением задачи (модели) дележа является вектор $Y=(y)_{i \in I}$, описывающий доли игроков $y_{i}$ такие, что

$$
\sum_{i \in I} y_{i}=r \text { и } 0<y_{i} \leq x_{i}^{\max } \forall i \in I
$$

Прокомментируем решение.

Основным принципом оптимальности в кооперативных играх является стремление игроков к ситуациям равновесия. Этот принцип оптимальности иногда называют принципом осуществимости цели, так как только ситуации равновесия могут быть предметом предварительных соглашений, которые будут соблюдаться. Если, например, в договоре зафиксирована неравновесная ситуация, то хотя бы одна из сторон будет заинтересована в нарушении договора и цель фактически не будет достигнута. Иными словами, нас интересуют такой дележ, который обеспечит устойчивость финансовых отношений в нашей кооперации стейкхолдеров при реализации стратегии, тем самым гарантируя достижение поставленных целей.

Из всего множества теоретико-игровых оптимумов (см., например, [Губко, Новиков, 2005]), учитывая доступную информацию, мы остановимся на N-ядре. N-ядро - это решение, основанное на минимизации степени неудовлетворённости выигрышем участников игры. Многие игровые оптимумы не имеют четкого математического алгоритма по их поиску. Для игры с двумя или тремя игроками существует графический метод определения N-ядра, но для нашего случая, когда количество стейкхолдеров после классификации может достигать сотни, этот метод неприемлем. Нобелевский лауреат по экономике математик И. Ауман вместе с М. Машлером сформулировали алгоритм поиска решения-вектора кооперативной игры [Aumann, Maschler, 1985], которое принадлежит N-ядру (математически ядро - это область). Авторы назвали свой алгоритм «методом Талмуда», так как он базируется на примере ветхозаветного описания дележа наследства. Именно «методом Талмуда» мы хотим воспользоваться для поиска баланса интересов. 
Показатель ресурса $\mathrm{r}$ в задаче дележа определяется по финансовой модели исходя из показателей финансовых интересов стейкхолдеров. Как правило, он сводится к различным показателям прибыли, добавленной стоимости, приросту стоимости бизнеса или комбинации этих показателей.

Решение задачи (4) методом Талмуда $\mathrm{Y}_{\mathrm{tal}}$ выглядит следующим образом:

$$
Y_{\text {tal }}=\operatorname{tal}(I, r, X)=
$$

$$
=u g_{i}\left(I, \min \left\{r, \frac{x_{i}}{2}\right\}, \frac{X}{2}\right)+u l_{i}\left(I,\left(r-\frac{x_{i}}{2}\right)_{+}, \frac{X}{2}\right) \text {, }
$$

где:

$X=\sum_{i \in I} x_{i}$

$u g_{i}(I, r, X)=\min \left\{\lambda, x_{i}\right\}, \lambda$ - решение уравнения $\sum_{i \in I} \min \left\{\lambda, x_{i}\right\}=r, u g$ (Uniform Gains)метод равномерных выигрышей.

$$
u l_{i}(I, r, X)=\left(x_{i}-\mu\right)_{+}, \quad \mu \quad-\quad \text { решение уравнения } \sum_{i \in I}\left(x_{i}-\mu\right)_{+}=r, \quad \text { здесь }
$$

$\left(x_{i}-\mu\right)_{+}=\max \left(0, x_{i}-\mu\right), u l$ (Uniform Losses) - метод равномерных потерь.

«Метод Талмуда «половинит» каждый интерес и следует методу равномерных выигрышей до тех пор, пока не удовлетворены половинные претензии. Затем применяется метод равномерных потерь до удовлетворения оставшихся половинных интересов» [Печерский, Беляева, 2001]. Учитывая иерархичность в формулировке внутрикорпоративных интересов, можно считать, что дополнительным преимуществом метода Талмуда является аксиома согласованности, которая гласит, что удаление одного или нескольких игроков из множества I, с одновременным удалением ресурсов, принадлежащих им, не меняет распределение долей в оставшемся множестве. Другими словами, решение задачи при балансировке интересов по трем уровням (включая внутрифирменный между подразделениями и персональный внутри подразделений) в три этапа (три игры) и в один этап (одну игру), когда интересы всего персонала холдинга, каждого менеджера, специалиста и рабочего формулируются сразу «в куче», идентичны.

Рассмотрим ситуацию выхода нашего холдинга на IPO.

Игроки: «старые» акционеры (А1), «новые» акционеры - инвесторы IPO (A2), инвестиционный банк (Б), совет директоров (СД), управляющая компания (УК), продуктовые компании $(\mathrm{j}$ - индекс ПК, $\mathrm{m}$ - количество ПК), бизнес-объекты $(\mathrm{k}$ - индекс БО, $\mathrm{n}$ - количество БО).

Стратегия содержит $\mathrm{n}$ инвестиционных проектов. Каждый ИП имеет свои характеристики, некоторые из них представлены в таблице:

\begin{tabular}{|l|c|c|c|c|c|c|}
\hline $\begin{array}{r}\text { Год (t)/ } \\
\text { показатель }\end{array}$ & 0 & 1 & 2 & 3 & 4 & 5 \\
\hline $\begin{array}{l}\text { Выручка } \\
\text { (Sales) }\end{array}$ & $\mathrm{s}_{0 \mathrm{k}}$ & $\mathrm{s}_{1 \mathrm{k}}$ & $\mathrm{s}_{2 \mathrm{k}}$ & $\mathrm{s}_{3 \mathrm{k}}$ & $\mathrm{s}_{4 \mathrm{k}}$ & $\mathrm{s}_{0 \mathrm{k}}$ \\
\hline EBITDA & ebitda $_{0 \mathrm{k}}$ & ebitda $_{1 \mathrm{k}}$ & ebitda $_{2 \mathrm{k}}$ & ebitda $_{3 \mathrm{k}}$ & ebitda $_{4 \mathrm{k}}$ & ebitda $_{5 \mathrm{k}}$ \\
\hline Инвестиции & inv $_{0 \mathrm{k}}$ & inv $_{1 \mathrm{k}}$ & inv $_{2 \mathrm{k}}$ & Inv $_{3 \mathrm{k}}$ & inv $_{4 \mathrm{k}}$ & inv $_{5 \mathrm{k}}$ \\
\hline NPV & $\mathrm{NPV}_{\mathrm{k}}$ & \multicolumn{5}{|l}{} \\
\hline
\end{tabular}

Из финансовой модели известно:

$$
N P V_{k}=\sum_{t=1} D C F_{k t}+T V_{k},
$$

где:

DCF - дисконтированный денежный поток в $\mathrm{t}$ год,

$\mathrm{TV}_{\mathrm{k}}$ - остаточная стоимость k-го проекта. 
TV в нашем примере рассчитывается по модели Гордона для бесконечно растущего свободного денежного потока:

$$
T V_{k}=\frac{C F_{T k}}{(1+W A C C)^{T+1}} \times \frac{1+T G R_{k}}{W A C C-T G R_{k}},
$$

где:

$\mathrm{CF}_{\mathrm{T}}$ - денежный поток в первый постпрогнозный год, взятый как равный денежному потоку в последний год проекта,

WACC - ставка дисконтирования (средневзвешенная стоимость капитала холдинга),

$\mathrm{TGR}_{\mathrm{k}}$ - темпы роста денежного потока в постпрогнозный период.

Прирост рыночной капитализации холдинга обеспечивается суммой $N P V$ проектов:

$$
\Delta \text { Мсар }=\sum_{k=1}^{n} N P V_{k} \text {. }
$$

$\mathrm{B}$ период времени $\mathrm{t}=0$ шла разработка стратегии и были сделаны первые инвестиции, в период $\mathrm{t}=1$ должно произойти IPO. В момент размещения рыночная капитализация предполагается Мсар ${ }_{1}$, причем она будет меньше плановой Мсар на определенный дисконт d, чтобы сохранить перспективы роста стоимости акций и акционеры IPO могли на этом заработать. После IPO капитализация по итогам года в момент времени $\mathrm{t}=2 \mathrm{Mcap}_{2}$ должна выйти на плановую Мсар:

$$
\begin{aligned}
& \text { Mcap }_{2}-\text { Mcap } \\
& \text { Mcap }_{2}=\text { Mcap }
\end{aligned}
$$

Дальнейшей ежегодный поступательный рост стоимости предполагается обеспечивать развитием инвестиционной программы (которая разрабатывается скользящим механизмом планирования), а также иными «фундаментальными» и «техническими» факторами (например, повышением эффективности операционных («старых») активов, уменьшением инвестиционного риска, ростом ликвидности акций и т.д.).

Выручка холдинга по стратегии $\mathrm{S}$ складывается из выручки ПК: $\sum_{j=1}^{m} S_{j}$, а последняя, в свою очередь, - из выручки по ИП данной ПК $S_{j}=\sum_{k \in j} s_{k}$. Предполагается, что принципы консолидации соблюдены.

$$
S=\sum_{j=1}^{m} S_{j}=\sum_{k \in 1}^{n} S_{k}
$$

Аналогично по $E B I T D A$ и инвестициям:

$$
\begin{aligned}
& \text { EBITDA }=\sum_{j=1}^{m} \sum_{t=0}^{T} \operatorname{EBITDA}_{t j}=\sum_{k=1}^{n} \sum_{t=0}^{T} e b i t d a_{t k}, \\
& I n v=\sum_{j=1}^{m} \sum_{t=0}^{T} \operatorname{In} v_{t j}=\sum_{k=1}^{n} \sum_{t=0}^{T} i n v_{t k} .
\end{aligned}
$$

Всю инвестиционную программу Inv планируется финансировать из трех источников - вложений «новых» акционеров, реинвестирования части EBITDA от существующих активов, принадлежащих «старым» акционерам, и долговых инструментов. Соответствующие доли известны:

$$
\begin{aligned}
& I n v=P_{A 1} I n v+P_{A 2} I n v+P_{D e b t} I n v, \\
& P_{A 1}+P_{A 2}+P_{D e b t}=1 .
\end{aligned}
$$

Также известны доли игроков А1 и А2 в структуре нового акционерного капитала (после IPO): 
$q_{A 1}+q_{A 2}=1$.

(2).

Значение рыночной капитализации без стратегии (инвестиций) известно из формулы

Перейдем к формулировке интересов.

Игрок А1 ориентируется на получение целевой доходности $\hat{Z}_{A 1}$ вложенного капитала:

$x_{A 1}\left(P_{A 1}, I n v\right)=\hat{Z}_{A 1} P_{A 1} \operatorname{Inv}=T \hat{V}-$ Mcap $_{\text {old }}$

(здесь и далее знак «^» над показателем означает, что это желаемое игроком значение).

Игрок А2 также имеет свой интерес по доходности $\hat{Z}_{A 2}$ вкладываемых средств, стремясь понизить цену размещения акций и соответствующую капитализацию $M c a p_{I}$ :

$$
x_{A 2}\left(P_{A 2}, \operatorname{In} v\right)=\hat{Z}_{A 2} P_{A 2} \operatorname{In} v=q_{A 2} \operatorname{Mcap}_{2}-P_{A 2} \operatorname{In} v=q_{A 2}\left(d+\text { Mcap }_{1}\right)-P_{A 2} \operatorname{Inv} .
$$

Совет директоров, принимавший решение по ИП и отвечающий за их реализацию, рассчитывает на долю $\hat{\alpha}$ в приросте стоимости:

$$
x_{C д}=\hat{\alpha}\left(T V-\text { Mcap }_{\text {actual }}\right) \text {. }
$$

Инвестиционный банк ориентируется на процент (долю) $\hat{\beta}$ от привлеченных на IPO средств, поэтому стремится максимизировать и свою долю и капитализацию при размещении Mcap $_{1}$ :

$$
x_{5}=\hat{\beta} \cdot \hat{M} \operatorname{cap}_{1} .
$$

Вклады УК, ПК и БО в реализацию стратегии определяются в соответствии с матрицей инвестиционной ответственности. Бонусы этих игроков в нашем примере привязаны к показателям выручки, EBITDA и инвестициям по принципу (3).

УК рассчитывает на бонус $\hat{\gamma}$ :

$x_{\text {УK }}=\hat{\gamma}\left(a_{1} S+a_{2} E B I T D A+a_{3} I n v\right)$,

каждая ПК - на бонус $\hat{\delta}_{j}$ :

$x_{\Pi K j}=\hat{\delta}_{j}\left(b_{1 j} S_{j}+b_{2 j}\right.$ EBITDA $\left._{j}+b_{3 j} \operatorname{Inv}_{j}\right)$,

каждый БО - на бонус $\hat{\varphi}$ :

$x_{5 O, k}=\hat{\varphi}_{k}\left(c_{1 k} s_{k}+c_{2 k}\right.$ ebitda $\left._{k}+c_{3 k} i n v_{k}\right)$,

причем $\mathrm{a}_{1}, \mathrm{a}_{2}, \mathrm{a}_{3}, \mathrm{~b}_{1}, \mathrm{~b}_{2}, \mathrm{~b}_{3}, \mathrm{c}_{1}, \mathrm{c}_{2}, \mathrm{c}_{3}>0$ и $\mathrm{a}_{1}+\mathrm{a}_{2}+\mathrm{a}_{3}=1, \mathrm{~b}_{1}+\mathrm{b}_{2}+\mathrm{b}_{3}=1, \mathrm{c}_{1}+\mathrm{c}_{2}+\mathrm{c}_{3}=1$.

Вектор желаемых выгод $X$ :

$X\left(x_{A 1}\left(\hat{Z}_{A 1}\right), x_{A 2}\left(\hat{Z}_{A 2}\right), x_{C Д}(\hat{\alpha}), x_{5}\left(\hat{\beta}, \hat{M} c a p_{1}\right), x_{\text {УK }}(\hat{\gamma}), x_{\Pi K j}\left(\hat{\delta}_{j}\right), x_{5 O, k}\left(\hat{\varphi}_{k}\right)\right)$

после согласования интересов примет вид $Y$ :

$Y\left(y_{A 1}\left(Z_{A 1}\right), y_{A 2}\left(Z_{A 2}\right), y_{C Д}(\alpha), y_{B}\left(\beta, \operatorname{Mcap}_{1}\right), y_{\text {УK }}(\gamma), y_{\text {ПКј }}\left(\delta_{j}\right), y_{\text {БO,k }}\left(\varphi_{k}\right)\right)$.

То есть, например, конечный выигрыш УК:

$y_{\text {УK }}=\gamma\left(a_{1} S+a_{2} E B I T D A+a_{3} \operatorname{Inv}\right)$.

Аналогично для остальных игроков.

В нашем примере ресурсом $\mathrm{r}$ выступит следующее выражение:

$r=T V-$ Mcap $_{\text {actual }}-P_{A 2}$ Inv,

где TV - остаточная стоимость по активам холдинга.

Выразив интересы игроков и ресурс для дележа через связи финансовой модели, мы можем методом Талмуда найти сбалансированное решение игры - вектор $\mathrm{Y}_{\text {tal }}(6)$.

Каков экономический смысл баланса интересов для внутрикорпоративных игроков с точки зрения финансовой модели? По сути это всего лишь дележ маржи, которую сгенерируют предприятия холдинга за рассматриваемый период стратегии. А как делить внутри стратегии по годам? Учитывая различную инвестиционную ответственность и иерархичность отношений игроков, наиболее рациональным и справедливым видится такой механизм распределения, когда удовлетворение интересов поднимается снизу вверх по Выпуск \#2(10), 2009 
иерархии - от исполнителей к инвесторам - от БО к СД и акционерам. Этот механизм или принцип, условно назовем «обратные песочные часы» (рис. 4) и разберем его в следующих публикациях.

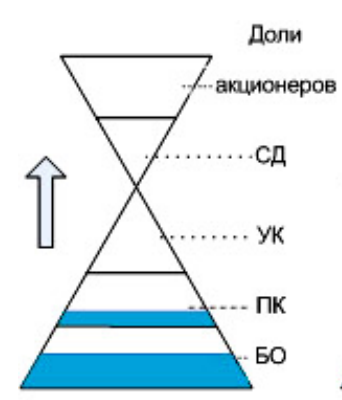

год 1

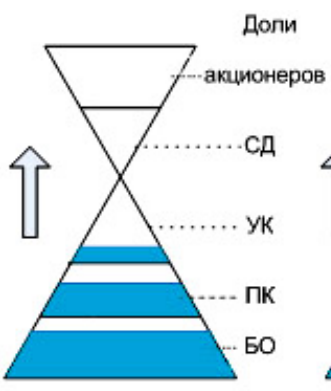

год 2

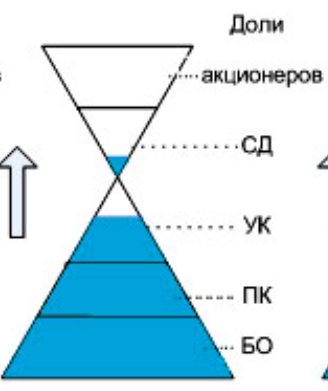

$\operatorname{rog} 3$

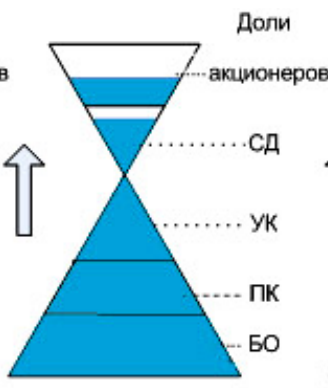

год 4

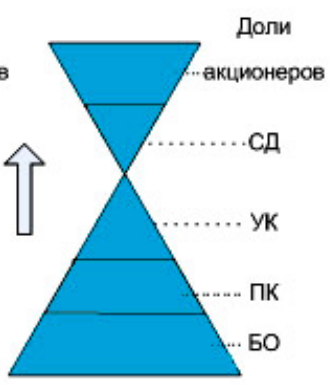

$\operatorname{rog} 5$

Рис. 4. Механизм распределения выгод внутрикорпоративных игроков по годам стратегического плана

Если интересы игроков формулируются вторым способом - минимаксным коридором - то, как правило, игра (4) отвечает следующему условию:

$$
\sum_{i \in I} x_{i}^{\min } \leq r<\sum_{i \in I} x_{i}^{\max }
$$

Тогда вместо решения (6) необходимо найти вектор $Y=(y)_{i \in I}$, описывающий доли игроков так, что:

$$
x_{i}^{\min } \leq y_{i} \leq x_{i}^{\max } \forall i \in I, \sum_{i \in I} y_{i}=r, \text { при этом } y_{i} \rightarrow x_{i}^{\max } .
$$

Как вариант, предлагается оптимум пропорционального дележа. Он осуществляется в два простых шага: сначала удовлетворяются нижние границы интересов: $r-\sum_{i \in I} x_{i}^{\min }$, затем ресурс распределяется пропорционально оставшимся долям интересов:

$$
y_{i}=x_{i}^{\min }+\left(x_{i}^{\max }-x_{i}^{\min }\right) \rho \text { или } y_{i}=\frac{x_{i}^{\max }}{\sum_{i \in I} x_{i}^{\max }} \cdot r,
$$

где коэффициент пропорциональности $\rho=\frac{r-\sum_{i \in I} x_{i}^{\min }}{\sum_{i \in I} x_{i}^{\max }-\sum_{i \in I} x_{i}^{\min }}$.

Для случая с компанией, уже прошедшей IPO и разработавшей стратегический план без акционерного финансирования, задача поиска баланса интересов упрощается как минимум потому, что финансовые интересы игроков-акционеров становятся однородными.

Перейдем к задаче оценки риска конфликта интересов. Имеем две ситуации формулировки интересов - 1) когда аналитик выявил финансовые интересы из финансовой модели и представленных холдингом документов $x l_{i}$ и уже имеется некоторая структура дележа $\mathrm{Y}_{1}\left(\mathrm{y} 1_{\mathrm{i}}\right) ;$ и 2) когда аналитик заново интересы переформулировал $x 2_{i}$, основываясь на диалоге с представителями заинтересованных сторон и рыночных данных, при этом интересы, предположим, формулировались по максимум-подходу:

$$
\begin{aligned}
& \sum_{i \in I} x 1_{i}=r, x 1_{i}=y 1_{i}, \\
& \sum_{i \in I} x 2_{i}>r .
\end{aligned}
$$

Аналитик находит для второй ситуации баланс интересов вышеописанным способом, получая вектор распределения $\mathrm{Y}_{2}\left(\mathrm{y} 2_{\mathrm{i}}\right)=\mathrm{Y}_{\mathrm{tal}}$, а затем сопоставляет структуры векторов $\mathrm{Y}_{1}$ и 
$\mathrm{Y}_{2}$, определяя степень отклонения финансовых отношений стейкхолдеров от теоретикоигрового баланса, например, через показатель Q:

$$
Q=\frac{\sum_{i \in I}\left|y 1_{i}-y 2_{i}\right|}{r} \cdot 100 .
$$

При $\mathrm{y} 1_{\mathrm{i}}=\mathrm{y} 2_{\mathrm{i}}, \mathrm{Q}=0$, а если все $\mathrm{y} 1_{\mathrm{i}}=0$, то $\mathrm{Q}=100$. $Q$ растет по мере увеличения отклонений, заложенных в планы интересов игроков от расчетного баланса интересов. Также для показателя $Q$ можно использовать формулу дисперсии и другие показатели.

Экспертно пока можно предложить следующую шкалу для оценки риска:

\begin{tabular}{|l|l|}
\hline $\mathrm{Q} \in(0,15)$ & Риск отсутствует, интересы сбалансированы \\
\hline $\mathrm{Q} \in(15,30)$ & $\begin{array}{l}\text { Риск имеется, но он незначительный, однако инвесторам его следует } \\
\text { учитывать }\end{array}$ \\
\hline $\mathrm{Q} \in(30,50)$ & $\begin{array}{l}\text { Риск существенный, имеется достаточно высокая вероятность, что } \\
\text { компания не выйдет на запланированные показатели в указанные сроки }\end{array}$ \\
\hline $\mathrm{Q} \in(50,100)$ & $\begin{array}{l}\text { Риск максимальный, структура финансовых отношений потенциально } \\
\text { конфликтна, показатели плана в названные сроки достигнуты не будут }\end{array}$ \\
\hline
\end{tabular}

При формулировке интересов клиентов и поставщиков для их ввода в модель дележа аналитику можно руководствоваться сравнительным подходом. По клиентам сравнивается их выгода по сравнению с существующими рыночными продуктовыми аналогами, произведенными конкурентами эмитента. Традиционно рассматриваются цена и качество товара, последнее также переводится в денежное выражение. Аналогично по поставщикам. Необходимо также учесть степень конкуренции на рассматриваемых рынках.

\section{4. Выводы и заключение}

Несмотря на то что столкновения интересов носят ситуационный характер, ответом на проблему поиска баланса интересов стейкхолдеров в компании может быть достаточно универсальная и при этом четкая и точная методика.

Для нахождения баланса интересов при разработке стратегии нужно выполнить следующий комплекс организационно-аналитических мероприятий:

1) осуществить стратегическое планирование, включающее разработку финансовой модели по критерию максимизации стоимости бизнеса (для акционеров); должны быть предусмотрены несколько (минимум три) сценариев инвестирования, исходя из прогнозов динамики целевых рынков; в части оплаты персонала по инвестиционным проектам следует исходить только из окладной части;

2) выявить стейкхолдеров, структурировать и классифицировать их (для холдинговых структур актуально использование классификаторов на базе юридической, управленческой и организационно-финансовой структур);

3) опросить представителей стейкхолдеров, выяснить и проанализировать обоснования ожидаемых ими экономических выгод от реализации стратегии (интересы формулируются минимаксным или максимум-подходом в рамках каждого сценария инвестирования). Сравнить ожидания с биржевой и отраслевой информацией;

4) спроецировать интересы на финансовую модель, получив финансовые интересы стейкхолдеров;

5) из финансовой модели вывести общий знаменатель финансовых интересов. Как правило, интересы сводятся к показателям финансовых результатов, приросту стоимости бизнеса или их комбинации; 
6) зная финансовые интересы и их общий знаменатель, построить кооперативную теоретико-игровую модель (задачу) дележа и найти ее решение (в качестве оптимума предлагается N-ядро);

7) скорректировать финансовую модель на основе полученных результатов, сообщить о найденном компромиссе стейкхолдерам, дождаться утверждения планов;

8) на заключительном этапе сформировать систему учета (мониторинга удовлетворенности) интересов как части управленческого учета компании.

Задача оценки риска конфликта интересов возникает при необходимости проверки заложенных в планы компании пропорций ожидаемых выгод стейкхолдеров. Для этой задачи предлагаем следующую методику:

1) выявить стейкхолдеров, структурировать и классифицировать их;

2) определить заложенные в планы интересы стейкхолдеров и вывести общий знаменатель финансовых интересов;

3) опросить представителей стейкхолдеров, выяснить и проанализировать обоснования ожидаемых ими экономических выгод от реализации стратегии. Сравнить ожидания с биржевой и отраслевой информацией;

4) спроецировать вновь выявленные интересы стейкхолдеров на финансовую модель, получить финансовые интересы;

5) построить кооперативную теоретико-игровую модель дележа и найти ее решение для вновь выявленных интересов;

6) сопоставить заложенные в планы пропорции выгод стейкхолдеров и найденный теоретико-игровой баланс интересов; определив степень отклонения интересов в планах от баланса, дать оценку вероятности возникновения конфликта интересов стейкхолдеров при реализации стратегии и, соответственно, вероятности достижения плановых показателей.

Одним из результатов балансировки интересов является корректировка целевой стоимости в стратегическом плане компании. Напомним, что стратегия разрабатывается по критерию Мсар $\rightarrow$ max, но, как правило, без системы бонусов для стейкхолдеров (за исключением, иногда, топ-менеджеров). Поэтому в вышеприведенном примере Мсар была максимально возможной, но нереалистичной рыночной капитализацией холдинга. Решением задачи поиска целевой стоимости компании Мсар ${ }^{*}$ может быть:

$$
\text { Mcap* }{ }^{*} \max \{\text { Mcap }: Y=\operatorname{tal}(I, r(\text { Mcap }), X)\} .
$$

Эта целевая стоимость, а точнее методика ее определения, и предлагается в качестве компромисса и своеобразного синтеза теорий максимизации ценности для акционеров и заинтересованных сторон. Первоначально стоимость получается за счет инвестиционной программы, построенной по критерию максимизации интересов акционеров, а затем корректируется балансом интересов стейкхолдеров.

Методики балансировки и оценки конфликтности интересов стейкхолдеров - это инструменты анализа и оптимизации планов корпорации, ее организационно-финансовой структуры, системы мотивации и вознаграждения, привязанной к реализации планов. Приведенный выше пример балансировки интересов внутрикорпоративных игроков (за исключением инвестиционного банка) при константе интересов поставщиков и клиентов стартовый пример для аналитиков. По-настоящему стратегическим инструментом анализа методики становятся, когда вопрос кооперации для компании шагает за ее пределы - с выходом на поиск баланса интересов сначала с поставщиками и клиентами, а затем - и с заинтересованными государственными и общественными структурами. Если корпорации начнут стратегически балансировать свои интересы с поставщиками и клиентами (хотя бы по входящим-исходящим ценам на сырье и продукцию), то во многих отраслях экономики могут сформироваться высокоустойчивые бизнес-цепочки, создающие основу для реального долгосрочного роста благосостояния всей экономики государства и уровня жизни ее населения. По мнению рейтингового агентства S\&P, учет интересов государственных и 
общественных структур также необходим, так как «нерешенные социальные и экологические вопросы компании чреваты финансовыми рисками и поэтому должны приниматься во внимание при проведении кредитного и фондового анализа эмитентов и при подписании страховых договоров» [Даллас, 2004].

Риск конфликта финансовых интересов, или риск финансового конфликта (РФК), может быть использован не только как инструмент анализа реализуемости стратегических и бизнес-планов, но и как элемент системы корпоративного риск-менеджмента. Внешним аналитикам его можно использовать для сравнения компаний, например, как альтернативную форму оценки показателя $\mathrm{CaR}$ (Capitalization at Risk). Рейтинговые агентства в интересах широкого круга инвесторов могут оценивать вероятность отрицательных отклонений в показателях выручки, прибыли и соответственно стоимости акций компаний. Консалтинговые фирмы, помогающие компаниям разрабатывать стратегические планы, могут через РФК оценивать степень готовности компаний к реализации своих планов.

Задачи определения баланса и конфликта интересов дают «новую жизнь» модели дисконтированных денежных потоков компании. Она становится ключевым инструментом управления стоимостью бизнеса, базисом для учета и мониторинга удовлетворенности интересов стейкхолдеров.

Для дальнейших исследований выскажем гипотезу о высокой корреляции РФК компании и инвестиционного риска инвесторов фондового рынка.

Задача поиска баланса интересов при разработке стратегии - далеко не единственное направление использования теории игр в корпоративных финансах. Последние призваны ответить на три взаимосвязанных вопроса: куда и сколько инвестируем, откуда и как привлекаем капитал и как делим результаты. Теоретико-игровой аппарат, в частности его кооперативный раздел, дает новые ответы на последний вопрос, причем для самых различных случаев. Поэтому спектр использования весьма значителен. Предлагаемые теорией игр модели и критерии оптимальности уже перевернули многие процессы в военных и многих экономических областях. Подошла очередь и финансовой науки.

Особенно подчеркнем, почему важно искать баланс интересов стейкхолдеров крупным корпоративным структурам до начала реализации планов - потому что такие структуры громоздки и инерционны, неправильно заложенные пропорции выгод стейкхолдеров очень трудно менять в процессе реализации планов.

Финансовые диспропорции в дележах - частое явление в современном деловом мире. Поэтому, возможно, будет актуальным становление финансовой конфликтологии как полноценного раздела корпоративных финансов. Вышеприведенной модели для этой цели, очевидно, недостаточно. Необходимо рассмотреть ситуации конфликта интересов на различных стадиях жизненного цикла компании, выявить специфику и особенности интересов стейкхолдеров. Модельный ряд также должен быть дополнен динамическими моделями (вдобавок к структурным), с изучением соответствующих свойств финансовых конфликтов.

Одной из задач данной статьи являлась попытка акцентировать внимание собственников и руководителей компаний на том факте, что для управления финансами им необходимо тщательно формулировать и обосновывать свои финансовые интересы, а также выявлять требования и ожидания других заинтересованных сторон компании, в частности, исполнителей стратегии. Попытка «повесить» реализацию стратегии на операционные подразделения была и будет обречена на провал. Необходимо искать компромисс и вести учет интересов. Если это делать, то риски реализации даже самых сложных, амбициозных и долгосрочных инвестиционных проектов будут сведены к минимуму.

Конечно, этап согласования интересов болезнен для акционеров и топ-менеджеров, как главенствующих сил в корпорации, но именно им необходимо периодически напоминать прописные деловые истины, что «надо договариваться» и «играть по правилам». Стоит 
упомянуть, что более $80 \%$ IPO, проведенных российскими компаниями, не оправдали ожидания инвесторов и не показали заявленной динамики роста своих бумаг. Доверие к российским компаниям со стороны западных инвесторов подорвано. Его нужно восстанавливать - стратегии следует планировать и реализовывать. Для западных инвесторов стоит сказать, что издержки конфликта интересов и вероятность финансовых трудностей у компаний, чья стоимость в значительной мере зависит от перспектив роста, очень высокие. Поэтому оценку риска конфликта интересов нужно осуществлять.

Наконец, можно озвучить главное допущение проведенного исследования - оно ориентировано только на тех предпринимателей и руководителей, которые осознают важность и необходимость поиска баланса интересов стейкхолдеров. Тем же, кто не желает его искать, следует разъяснять, что «договариваясь» и «играя по правилам» они заработают на стратегическом горизонте планирования значительно больше, нежели в том случае, если будут отнимать краткосрочную выгоду у других стейкхолдеров. Если разъяснений будет недостаточно, то, возможно, стоит продумать «карательные» меры законодательного характера, иначе роста благосостояния российскому обществу и выхода из «сырьевой» ямы отечественной экономике в ближайшие десятилетия не видать.

\section{Список литературы}

1. Байбурина Э.Р., Головко Т.В. Эмпирическое исследование интеллектуальной стоимости крупных российских компаний и факторов ее роста // Корпоративные финансы. - 2008. - № 2(6). - С.5-19.

2. Байбурина Э.Р., Ивашковская И.В. Роль интеллектуального капитала в создании стоимости российских компаний // Вестник Финансовой академии. - 2007. - № 4(44). - C.53-62.

3. Брауде А., Ефименко О., Леонова И. Инвестиционный проект: управление мотивацией // Управление компанией. - 2004. - № 1. - С. 33-37

4. Губко М.В., Новиков Д.А. Теория игр в управлении организационными системами. Издание второе. - М.: 2005.

5. Даллас Д. Корпоративное управление и устойчивое развитие как факторы риска, 2004: http://www.csrjournal.com/main/1381-dzhordzh-dallas-korporativnoe-upravlenie-i.html.

6. Добровольский Е., Карабанов Б., Боровиков П., Глухов Е., Бреслав Е., Бюджетирование: шаг за шагом. - СПб.: Питер, 2006.

7. Дымшаков А. В. Мотивация инвестиционных проектов // Менеджмент в России и за рубежом. - 2004. - № 8. - С . 138-144.

8. Ивашковская И.В. Модель стратегического стоимостного анализа фирмы // Экономическая наука современной России. - 2008. - № 3(42). - С.115-127.

9. Ивашковская И.В. Стратегический мониторинг создания стоимости для всех стейкхолдеров компании // Вестник Финансовой академии. - 2008. - № 3(47). - С.6985.

10. Идрисов А.Б., Картышев С.В., Постников А.В. Стратегическое планирование и анализ эффективности инвестиций. - М.: Филин, 2003.

11. Куршева С. Проектная мотивация //Акционерное общество. - 2006. - № 10(29). - С. $18-22$.

12. Марк К. Скотт. Факторы стоимости: Руководство для менеджеров по выявлению рычагов создания стоимости / пер. с англ. - М.: ЗАО «Олимп-Бизнес», 2005.

13. Мулен Э. Кооперативное принятие решений: аксиомы и модели. - М.: Мир, 1991.

14. Петров М.А. Механизмы согласования позиций заинтересованных сторон в процессе разработки и реализации стратегии фирмы: Автореферат диссертации... на соискание ученой степени к.э.н. СПб.: 2005. - С.4. 
15. Печерский С.Л., Беляева А.А. Теория игр для экономистов. Вводный курс. Учебное пособие. - СПб.: издательство Европейского университета в Санкт-Петербурге, 2001.

16. Процессно-ориентированное бюджетирование. Внедрение нового инструмента управления стоимостью компании / Джеймс Бримсон, Джон Антос при участии Джея Коллинга; пер. с англ. В.Д. Горюновой; под. общ. ред. В.В. Неудачина. - М.: Вершина, 2007.

17. Санин В.В. Постановка финансовой цели банка: формирование новых подходов // Финансы и кредит. - 2004. - № 6 (144). - С.31-36.

18. Стратегия корпоративной социальной ответственности МДМ Банка, 2007: http://www.mdmbank.ru/common/data/pub/files/24580/MDM_CSR_Strategy_Rus.pdf.

19. Стратегия и приоритеты корпоративной социальной ответственности МБРР, 2008 : http://www.mbrd.ru/editor/uploads/files/kso_mbrd.pdf

20. Фут Н., Хенсли Д., Лэндсберг М., Моррисон Р. Роль корпоративного центра // Вестник McKinsey, - 2003. - №1(3). -C.46-55.

21. Aumann R.J., Maschler M. (1985). Game theoretic analysis of a bankruptcy problem from the Talmud //Journal of Economic theory. 36. 195-213.

22. Freeman, R.E. (1984), Strategic Management: A Stakeholder Approach. - Boston: Pitman Publishing.

23. Michael C. Jensen (2001), Value maximization, Stakeholder theory, and the Corporate objective function, The Monitor Group and Harvard Business School, (2001) 11-16.

24. Standard \& Poor's, официальный

сайт: http://www.standardandpoors.ru/page.php?path=services\#2. 